\title{
老年者における日常生活状態（QOL：ADL，HDS-R，
}

\section{GDS など）と手術後のせん妄など異常行動について}

\author{
橋本 肇 山城 守也
}

＜要 約> 目的：老年者の手術では術後に発生するせん妄が術後管理の面で大きな問題となってい る. 今回身体状況, 日常生活状態, 視覚, 聴覚, 疾呆程度, 精神状態 (うつ), 社会活動, 家庭生活など の術前状態と術後のせん妄など異常行動との関係について検討した。

方法：身体状況は疾患, 併存疾患, 視力, 聴力を 4 段階に評価した. 日常生活 (ADL) は食事, 用便, 衣服の着脱, 洗面, 入浴, 起座, 歩行を総合し評価した。痴呆は Clinical Dementia Rating (CDR), 改訂長谷川式簡易知能評価スケール (HDS-R) で評価した。うつは Geriatric Depression Scale (GDS) で評価した。社会活動，家庭生活は 4 段階評価した。可能なものは自己評価とした。術後せん妄は術後 に異常な行動，幻覚，興奮，失見当識，不眠などを示し，治療を必要としたものとした。疾呆患者では 術後の異常行為がせん妄によるか判定困難な症例もあったので「せん妄など異常行動」とし一括した.

症例：1992 1993年に中等度以上の手術をし，術後 ICU に入室した. 160 人 (男70人，女 90 人，平均年 齢76.3 \pm 7.5 歳) を対象とした.

結果：術後せん妄など異常行動は 52 人（32.5\%）に見られた。

身体状況とせん妄など異常行動の頻度との関係では疾患の重症度, 視力との関係は見られず, ADLの 低下, 聴力障害で有意な増加が見られた。痴呆との関係ではその頻度は HDSR スコアと逆相関し, CDR の程度と相関していた。うつでは GDS でうつ傾向のあるものでせん妄など異常行動が多く見られたが 有意差ではなかった，社会活動をするものでせん妄など異常行動は少ないが有意差ではなく，家庭生活 とは関係が見られなかった。

結論：老年者では ADL, 知能, 聴力に障害ある患者で術後せん妄など異常行動が高頻度で見られた。

Key words : 術後せん妄, 術後 QOL とせん妄, 痴呆とせん妄

\section{1. 緒 言}

老年者の手術後に見られるせん妄は患者管理を困難 にするもので，臨床上大きな問題になっている．この せん妄の原因は明らかではなく, 種々の要因が加わっ た症候群と考えられるが, 術前の患者状態もその一つ の要因をなすと考えられている，老年者では高齢者， 男性, 大手術後, 痴呆患者に術後のせん妄が多いとい われる11.また従来より運動性の低下した患者, 視力障 害にせん妄が多いとされ，それらとの関係が注目され ている ${ }^{2) \sim 5)}$. しかし系統的に患者の術前の日常生活状 態などとせん妄の関係を調べた報告はいまだ少ない.

今回術前の患者の QOL と術後のせん妄など異常行 動との関係を検討した. 老年者の QOL は身体, 疾患面

H. Hashimoto, M. Yamashiro：東京都老人医療セン 夕一外科

受付日：1994.2. 7, 採用日：1994. 5.20
のみからでなく, 知能面, 精神面, 社会活動, 家庭生 活などから評価すべきとされているので，それに従い 評価した ${ }^{6)}$.

鼠径ヘルニアなどの軽症疾患ではせん妄が極めて少 ないので7)，今回は軽症疾患を除いた。

\section{2. 症例と方法}

1) 症例

1992～1993年に外科で中等度以上の手術を行った， 男70例, 女90例, 計 160 例, 年齢60 93歳 (平均 $76.3 \pm$ 7.5歳)について検討した. 手術を行った疾患は表 1 の 如くである。

2) $\mathrm{QOL}$ 評価

QOL 評価にはできるだけ評価の定まった評価法を 使用することにしたが, 社会活動, 家庭生活の評価に は簡単な評洒法を作成した。

A）身体面 
表 1 主疾患の重症度と疾患名

\begin{tabular}{|c|c|c|}
\hline \multirow[t]{2}{*}{ やや軽症 } & 胆襄胆石症 & 14 \\
\hline & 乳癌 & 4 \\
\hline \multirow[t]{2}{*}{ 24例 } & ヘルニア嵌屯 & 2 \\
\hline & その他 & 4 \\
\hline \multirow[t]{2}{*}{ 中等症 } & 胃癌（早期） & 25 \\
\hline & 結腸直腸癌（切除容易） & 27 \\
\hline \multirow[t]{3}{*}{ 88例 } & 総胆管結石他 & 13 \\
\hline & 末梢動脈疾患 & 10 \\
\hline & その他 & 13 \\
\hline \multirow[t]{2}{*}{ 重症 } & 胃癌，肉腫（進行） & 20 \\
\hline & 結腸直腸癌（切除困難） & 10 \\
\hline \multirow[t]{3}{*}{ 48例 } & 膵癌 & 7 \\
\hline & 食道癌 & 4 \\
\hline & その他 & 7 \\
\hline
\end{tabular}

a）主疾患，併存疾患：主疾患は軽度を除き，胆囊胆 石症，乳癌などをやや軽症，早期胃癌，手術の容易な 大腸癌, 手術の困難な良性疾患を中等症, 進行癌, 大 動脈瘤などを重症とした。併存疾患は無いか存在して も治療の必要のないものを「軽症」, 存在しても生活に は殆ど支障のないものを「やや軽症」, 治療を必要とす る疾患のあるものを「中等症」，いつでも生命の危険に なりうるものを「重症」の 4 段階にわけた。

b) 生活動作 (ADL) : 食事, 用便, 衣服の着脱, 洗 面, 入浴, 歩行, 起立, 起坐についてそれぞれ 5 段階 の自己評価を行い，その合計点数でADLの良い ADL-5から非常に悪い ADL-1までの 5 群に分けた。

c) 視力, 聴力 : 眼鏡, 補聴器などは使用したまま日 常生活から第 $5 ， 6$ 表の如く 4 段階の評価を行った. 眼鏡使用 31 名, 補聴器使用 3 名であった。

B) 知能面

a) Clinical Dementia Rating (CDR) を用いて 5 段 階評価を特定の医師が行った ${ }^{8)}$.

b) 改訂一長谷川式簡易知能検査スケール (HDS-R) を特定の医師が行いスコア化した ${ }^{9)}$. 5 点毎の群に分 け検討した。

C) 精神面

a)「うつ」状態：Geriatric Depression Scale (GDS) (Sheikh) を使用した ${ }^{10)}$. 質問用紙に解答を自己記入さ せ， $0 \sim 5$ を正常， 6 〜 10を軽度「うつ」, 11〜15を重 症「うつ」とした.一部しか解答のないものは無解答 とした。

D) 社会面

a）社会活動：「町内会, 老人クラプなどへの参加を よくする, 時々する, あまりしない, 全然しない」の
4 段階で評価した。

b）家庭生活：「家族との関係を, 非常に良い, 良い, 普通，覀い」の質問に自己記入させ評価した。

自己評価のできない痴呆患者 3 名では ADL, 社会活 動を家族が評価した。しかし「うつ」, 家庭生活の評価 は行わなかった。

3）原則として手術の約 1 週前に評価した。

4）せん妄及び異常行動

せん妄の診断は術後一定の時間をおいて「急に起 こった全体的認知障害で, 睡眠障害, 異常行動を伴う もの」とした ${ }^{21}$. 主な症状は異常な発語, 幻覚, 異常行 動, 見当識消失, 不眠などである. 痴呆患者の術後の 異常行動は疾呆によるかせん妄によるかは鑑別が困難 であるので, 今回は「せん妄など異常行動」と一括し て検討した。

5） $\chi^{2}$ 検定を行った.

\section{3. 結 果}

せん妄など異常行動は男で 70 人中 26 人（37.1\%）女 90 人中 26 人 $(28.9 \%)$ に見られた。

自己評価では各項目で全員の回答が得られなかっ

表 2 評価, 回答率（160人中）

\begin{tabular}{l|c|c}
\hline & 評価回答数 & 率 $\%$ \\
\hline 主疾患 & 160 & 100 \\
\hline 併存疾患 & 160 & 100 \\
\hline $\mathrm{ADL}$ & 133 & 83.1 \\
\hline 視力 & 93 & 58.1 \\
\hline 聴力 & 93 & 58.1 \\
\hline CDR & 160 & 100 \\
\hline HDSR & 145 & 90.6 \\
\hline うつ度 & 66 & 41.4 \\
\hline 家庭 & 85 & 53.1 \\
\hline 社会 & 73 & 45.6 \\
\hline
\end{tabular}

表 3 疾患程度と術後せん妄など異常行動

\begin{tabular}{|c|c|c|c|c|}
\hline \multicolumn{3}{|c|}{ 主疾患 } & \multicolumn{2}{|c|}{ 併存疾患 } \\
\hline & 症例数 & $\begin{array}{c}\text { 術後せん妄など } \\
(\%)\end{array}$ & 症例数 & $\begin{array}{c}\text { 術後せん妄など } \\
(\%)\end{array}$ \\
\hline 軽 症 & - & - & 54 & $11(20.4)$ \\
\hline やや軽症 & 24 & $5(20.8)$ & 63 & $26(41.3)$ \\
\hline 中等症 & 88 & $29(33.0)$ & 33 & $12(36.4)$ \\
\hline 重症 & 48 & $18(37.5)$ & 10 & $3(30.0)$ \\
\hline
\end{tabular}


表 4 術前 $\mathrm{ADL}$ と術後せん妄など異常行動

\begin{tabular}{c|c|c}
\hline $\mathrm{ADL}$ & 症例 & 術後せん妄など $(\%)$ \\
\hline 1 & 4 & $3(75.0)$ \\
\hline 2 & $5^{*}$ & $2(40.0)$ \\
\hline 3 & $7^{* *}$ & $4(57.1)$ \\
\hline 4 & 23 & $13(56.5)$ \\
\hline 5 & 94 & $17(18.1)$ \\
\hline 不明 & 27 & $13(48.1)$ \\
\hline
\end{tabular}

* : 痴呆で家人が評価

表 5 視力と術後せん妄など異常行動

\begin{tabular}{l|c|c}
\hline & 症例数 & 術後せん妄など \\
\hline 日常生活に支障なし & 63 & $14(22.2 \%)$ \\
\hline 大きな字は読める & 22 & $10(45.5 \%)$ \\
\hline 人の顔は判る & 8 & $2(25.0 \%)$ \\
\hline 明暗が判る & - & - \\
\hline 不 明 & 67 & $26(38.8 \%)$ \\
\hline
\end{tabular}

表 6 聴力と術後せん妄など異常行動

\begin{tabular}{l|c|c}
\hline & 症例数 & 術後せん妄など \\
\hline 問題なし & 68 & $13(19.1 \%)$ \\
\hline 大声が必要 & 18 & $7(38.9 \%)$ \\
\hline 大声, ゆっくり, 反復 & 7 & $4(57.1 \%)$ \\
\hline 全く聞こえない & - & - \\
\hline 不 明 & 67 & $25(37.3 \%)$ \\
\hline \multicolumn{2}{|r}{}
\end{tabular}

た. 各項目の評価, 回答率は第 2 表の如くである.「う つ, 家庭生活, 社会活動などの評価, 回答が少なかつ た。

\section{1）主疾患，併存疾患}

患者の程度とせん妄など異常行動の関係を見たが, 主疾患では中等症群, 重症群に多くせん妄など異常行 勢が見られているが，統計的に有意差ではなかった。

併存疾患では軽症群で少なくやや軽症以上の群で増 加しているが, その程度とせん妄など異常行動の発生 には関係が見られなかった。

2）日常動作 (ADL)

術前の ADL に問題のない ADL-5群ではせん妄な ど異常行動が $18.1 \%$ とやや少ないが, ADL に軽度以上 の低下がある ADL-4以上の群では多く見られ, 重度の
表 7 痴呆 (CDR) と術後せん妄など異常行動

\begin{tabular}{c|c|c}
\hline 知 能 $(\mathrm{CDR})$ & 症例 & 術後せん妄など $(\%)$ \\
\hline 健 康 $(0)$ & 69 & $8(11.6)$ \\
\hline 痴呆の疑い $(0.5)$ & 54 & $18(33.3)$ \\
\hline 軽度痴呆 $(1)$ & 23 & $11(47.8)$ \\
\hline 中等度痴呆 $(2)$ & 12 & $8(66.6)$ \\
\hline 重度痴呆 $(3)$ & 2 & $2(100.0)$ \\
\hline \multicolumn{2}{l}{} & $\mathrm{p}<0.01$
\end{tabular}

表 8 HDSR と術後せん妄など異常行動

\begin{tabular}{c|c|c}
\hline HDSR スコア & 症例 & 術後せん妄など $(\%)$ \\
\hline $0 \sim 5$ & 3 & $2(66.6)$ \\
\hline $6 \sim 10$ & 7 & $4(57.1)$ \\
\hline $11 \sim 15$ & 11 & $5(45.5)$ \\
\hline $16 \sim 20$ & 23 & $11(47.8)$ \\
\hline $21 \sim 25$ & 47 & $12(25.5)$ \\
\hline $26 \sim 30$ & 54 & $3(5.6)$ \\
\hline
\end{tabular}

表 9 術前うつ（GDS）と術後せん妄など異常行動

\begin{tabular}{|c|c|c|c|}
\hline 棥度 & (GDS) & 症例 & 術後せん妄など（\%） \\
\hline 正常 & $(0 \sim 5)$ & 43 & $9(20.9)$ \\
\hline 軽度抑禁 & $(6 \sim 10)$ & 22 & $9(40.9)$ \\
\hline 重度抑麓 & $(11 \sim 15)$ & 1 & 0 \\
\hline 不明 & & 94 & $34 \quad(36.2)$ \\
\hline
\end{tabular}

障害であるADL-1群では 4 人中 3 人に見られた. ADL の低下とせん妄など異常行動の発生には有意の 関係が見られたが $(\mathrm{p}<0.01), \mathrm{ADL}$ 低下の程度とせん 妄など異常行動の頻度には相関は見られなかった。

3）視力, 聴力

視力, 聴力の高度な機能障害患者は今回はいなかっ た.

視力に問題のある症例群でせん妄など異常行動が多 く見られたが, 障害が強い例ではむしろ頻度は少な かった。

聴力では障害の程度に比例してせん妄など異常行動 が有意に多く見られた $(\mathrm{p}<0.05)$.

4) 痴呆とせん妄

知能面からの検討では, CDR では痴呆の疑い以上の 群でせん妄の頻度が増加し，しかも痴呆の程度に比例 
表10 家庭生活と術後せん妄など異常行動

\begin{tabular}{c|c|c}
\hline & 症例数 & 術後せん妄など $(\%)$ \\
\hline 非常に良い & 30 & $6(20.0)$ \\
\hline 良 い & 35 & $9(25.7)$ \\
\hline 普 通 & 18 & $4(22.2)$ \\
\hline 悪 い & 2 & $1(50.0)$ \\
\hline 不 明 & 75 & $32(42.7)$ \\
\hline
\end{tabular}

表11 社会活動と術後せん妄など異常行動

\begin{tabular}{l|c|c}
\hline & 症例数 & 術後せん妄など \\
\hline いつもする & 13 & $2(15.4 \%)$ \\
\hline 時々する & 27 & $5(18.5 \%)$ \\
\hline あまりしない & 15 & $5(33.3 \%)$ \\
\hline 全然しない & $18^{*}$ & $6(33.3 \%)$ \\
\hline 不 明 & 87 & $34(39.1 \%)$ \\
\hline \multicolumn{2}{|r}{$*$ : 痴呆 3 人は家人が評価 }
\end{tabular}

しせん妄の頻度が統計的に有意に増加していた（ $\mathrm{p}<$ $0.01)$.

HDS-Rではそのスコアに逆相関してせん妄の頻度 が統計的に有意に増加していた $(\mathrm{p}<0.01)$. とくに20 点以下の症例では 44 人中 22 人 $(50.0 \%)$ に見られ，21 点以上の 101 人中 15 人 $(14.9 \%)$ に比べ 3 倍以上の頻度 であった。

5)「うつ」とせん妄

今回 Geriatric Depression Scale (GDS) で評価し たが重症「うつ」の症例は 1 例のみであった。

軽度「うつ」群では正常群の 2 倍の頻度でせん妄が 見られたが，有意差ではなかった。

6）家庭生活, 社会活動とせん妄

家庭生活とせん妄の頻度には関係は見られなかっ た。

社会活動との関係では社会活動をする群でせん妄の 頻度は少なかったが, 有意差ではなかった。

\section{4. 考 察}

老年者の医療において近年 QOL 評価の必要性が云 われている. Applegate らは老年者の QOL は疾患の みではなく身体面, 知能面, 「うつ」の面, 社会面など 多角的に評価することが必要としている6). 今回はそ れに従い一定の評価のあるそれぞれの評価法を用い た。しかし項目が多いと患者の協力が十分得られない
ので，社会活動，家庭生活は簡単な評価法を作成し評 価した。 また可能な項目は自己評価し, 他は医師が評 価した。しかし痴呆患者で自己評価が出来ないもので は一部を家族に評価してもらった。従って, 評価基準 が必ずしも一定ではない項目ができた。痴呆患者の QOL の評価を如何にするか検討したがいまだ基準が ないようである。

老年者の手術後には 6 ～31.3\%に術後せん妄が発生 すると云われている(12)11)17). せん妄が多いのはより高 齢者, 男, 大手術後, ICU 利用患者, 手術時間の長い もの, 合併症のあるもの, 血液ガス, 電解質などの検 查值に異常があるものなどに多いといわれる ${ }^{11121}$. 術 後せん妄は手術後一定の平静期間のあとに発生し, 軽 快後は特に後遺症を残さないことから, 原因は中枢神 経系の器質的障害と考えられている. その原因として 手術時に使用した抗コリン作動薬, 侵襲ホルモン, $\mathrm{pO}_{2}$ の低下，睡眠不足などが指摘されているが，いまだ決 定的な因子は明らかでなく, 各要因の複合的な症候群 と考えられる ${ }^{13) \sim 16) 18) . ~}$

今回術前状態と術後せん妄など異常行動との関係を 検討した. 従来重症, 大手術後にせん妄が多いと云わ れているが, 今回の検討では手術の目的となった主疾 患との関係では, 重症にせん妄など異常行動が多く見 られたが有意差ではなかった。

併存疾患の重症度との関係では, 特に重症者に多い ものではなく,一見従来の報告と異なるようであるが, 今回の検討では主疾患が軽度を除いたためにせん妄な ど異常行動の頻度が高くなり, その中では併存疾患の 重症度と比例しなかったと考えている。

$\mathrm{ADL}$ の程度とせん妄発生の頻度を検討した報告は 少ない. Seymore は術前に運動性の低下している患者 には術後せん妄が多いと云う5). 今回の検討では $\mathrm{ADL}$ の低下した患者には術後にせん妄など異常行動の発生 が多く見られたが, その低下の程度と術後せん妄など 異常行動の頻度の関係は明らかでなかった。

視力障害とせん妄の関係は急性の視力障害後にせん 妄が多く見られることは Deuren らにより指摘されて いる4). 今回は視力障害が術前より存在した患者につ いて術後のせん妄など異常行動の発生頻度を検討した とことになるが, 軽度の視力障害患者に多く見られた が, 高度の障害患者ではむしろ少なくなっていた。こ れは高度の視力障害にたいしてはそれなりにケアする ための心理的反応の差であり, また何も見えないので 幻視をおこすことが少ないものとも考えられた。 
聴力障害と術後せん妄についての報告はなされてい ないようである，今回の検討では聴力障害患者では術 後せん妄など異常行動が多く見られ，その程度により 増加していた。

Kennedy は老年者では感覚が失われるとせん妄に なり易いと云う ${ }^{3)}$.

痴呆患者に術後せん妄が多いことは従来より指摘さ れている ${ }^{12)}$.しかしその診断基準については明らかで はないものが多い.小坂は痴呆にせん妄が加わった場 合の認知障害の鑑別診断は困難であるが, せん妄では 一過性の認知障害, 注意力障害から錯覚, 幻覚が多く, 睡眠リズムの障害が多く, 精神運動行動の障害が見ら れ, 感情面で易怒的となるという ${ }^{1920)}$. しかし現実に痴 呆患者で幻視, 幻聴のような術前には見られなかった 症状を示しせん妄によると診断できるものもあるが, 夜間不眠, 落ち着きのなさ, 異常行動など術前には見 られなかったものが出現しても, 手術侵襲, 環境の変 化を考慮するとせん妄によると一概には診断できない ことがある.

このような術後せん妄など異常行動は HDS-R, $\mathrm{CDR}$ で診た疾呆の程度と比例してその頻度が増加し ていた.

HDS-R は20/21が痴呆の鑑別のカットオフポイン トとなり, 得点は重症度の評価に有用であると云われ $3^{9}$. 今回 HDS-R の点数と術後せん妄など異常行動の 発生頻度に相関が認められた。

「うつ」については質問用紙に自分で記入するとい う方法をとったが, このような質問に答えるのが煩雑 と感じる患者が少なくなく, 回答率は低かった。また 当然ながら痴呆患者では回答を得ることができなかっ た.今回の調査症例中に高度の「うつ」を示したもの は少なかったが, 外科手術する前は不安がありながら も希望している状態で「うつ」は少ないものと考えら れた。

軽度「うつ」群でせん妄など異常行動が多く見られ た. Simpsonらは不安の強い患者にせん妄が多いとし ている ${ }^{21)}$.

老人の社会活動としては就業していることは少な く, 多くは町内会, 老人クラブの活動である.このよ うなところへ参加している患者にはせん妄など異常行 動は少なかった，社会活動に参加しているような患者 は痴呆が少なく, また入院しても比較的適応性の良い ものと考えられた。

家庭生活との関係ではせん妄など異常行動との間に
関係が見られなかった，家庭生活が良いとする患者の なかにはむしろ家人に甘える傾向があり, 病院に適応 するのが困難の患者が含まれると考えた。

社会活動, 家庭生活では解答のなかった不明群で比 較的多く術後せん妄など異常行動が見られ，このよう なアンケート調査の限界が考えられた。

老年者の手術後に見られるせん妄など異常行動の原 因は明らかでないが，種々の要因によると考えられて いる. 今回患者の術前の QOL と術後せん妄など異常 行動との関係について検討したが, CDR, HDS-R, $\mathrm{ADL}$, 聴力などとせん妄など異常行動の発生に有意の 相関が見られた。術前にこれらに注目し, 術後早期に 対策をとることができれば, 術後せん妄など異常行動 の発生を大いに抑制できるであろう。

\section{文献}

1) Morse R, Litin LM : Postoperative delirium: A study of etiologic factors. Amer J Psychiat $1969 ; 126: 388-395$.

2) Lipowsky ZJ : Transient cognitive disorders (delirium, acute confusional states) in the elderly. Am J Psychiatry $1983 ; 140$ : 1426-1436.

3) Kennedy A: Psychological factors in confusional states in the elderly. Gerontol Clin $1959 ; 1: 71-82$.

4) Deuren HV, Missotten L: Atropine intoxication and the acute delirium of the elderly blind patient. Bull Soc Belge Ophthalmol 1979; 186 : $27-29$.

5) Seymore DG, Pringle R: Post-operative complications in the elderly surgical patients. Gerontol $1983 ; 29: 262-270$.

6) Applegate WB, Blass JP, Williams TF: Instruments for the functional assessment of older patients. New Engl J Med $1990 ; 322: 1207$ $-1214$.

7) 橋本 肇, 中山夏太郎, 野呂俊夫, 高橋忠雄, 日野 恭徳, 平島得路ほか: 総合病院でみられる老年期 に行動異常一外科の立場から. 老年精神医学 $1986 ; 3: 80-84$.

8) 本間 昭: Clinical Dementia Rating (CDR). 高齢者のための知的機能検査の手引(大塚俊男, 本 間 昭 監修), ワールドプランニング, 東京, 1991, p65-69.

9）加藤伸司, 下垣 光, 小野寺敦志, 植田宏樹, 老川 


\section{賢三, 池田一彦ほか：改訂 長谷川式簡易知能評価 スケール (HDS-R) の作成. 老年精神医学 1991 ; $2: 1339-1347$.}

10) Sheikh JI, Yesavage JA, Raret L, Lum D : Geriatric depression scale : Recent evidence and development of a shorter version. In : Brink TL(ed) : Clinical Gerontorogist, Vol 5, Haworth Press, New York, 1986, p165.

11）山城守也, 中山夏太郎, 橋本 肇, 野呂俊夫, 高橋 忠雄, 日野恭徳: 高齢者における術後精神障害 一その発生因子について一.「外科」 $1980 ; 42: 661$ -667 .

12）山城守也: 高㢼者の術後精神障害. 消化器外科 1987 ; 10 : 143-149.

13) Rosenberg J, Kehlet H : Postoperative mental cnfusion-association with postoperative hypoxemia. Surgery $1993 ; 114: 76-81$.

14) Tune LE, Damlouji NF, Holland A, Gardner TJ, Folstein FF, Coyle JT: Association of postoperative delirium with raised serum levels of anticholinergic drugs. Lancet $1981 ; 26: 651$ -652 .
15) Cappenter WT, Gruen PH: Cortisols effects on human mental functioning. J Clin Psychopharm $1982 ; 2$ : $91-101$.

16) Johns MW, Large AA, Masterton JP, Dudley AF : Sleep and delirium after open heart surgery. Br J Surg $1974 ; 61$ : 377-381.

17）西山正彦, 吉田和弘, 頼島 敬, 田中 卓, 峠 哲 哉：80歳以上の高齢者胃癌手術と精神障害. 日消 外会誌 $1992 ; 25: 1942-1947$.

18) Seymore DG, Henschke PJ, Cape RDT : Acute confusional states and dementia in the elderly: The role of dehydration/volume depletion, physical illness and age. Age Ageing $1980 ; 9$ : 137-146.

19）小阪憲司：潪呆老人のせん妄. 老年精神医学 $1985 ; 2: 554-561$.

20）斉藤 伸, 飯塚禮二：せん妄の診断と治療. Geriat Med $1990 ; 28: 205-209$.

21) Simpson CJ, Kelette JK: The relationship between preoperative anxiety and postoperative delirium. J Psychosom Res 1987 ; 31 : 491 -497 .

\title{
Abstract
}

\section{Postoperative Delirium and Abnormal Behaviour Related with Preoperative QOL of Elderly Patients}

\author{
Hajime Hashimoto and Moriya Yamashiro
}

Postoperative delirium and abnormal behaviour were studied in 160 patients aged 60 and over with relation to their QOL assessed before surgical operation. QOL was assessed physically, psychologically, mentally and socially. Physical status was assessed with ability in daily life, seeing, hearing and severity of disease. Psychological condition (depression) was assessed by using GDS (Geriatric Depression Scale by Sheikh), Mentality (dementia) was assessed by using CDR (Clinical Dementia Rating) and HDS-R (Revised version of Hasegawa' s dementia Scale). Sociality was assessed by social life and familial enviroment. Postoperatively $37.1 \%$

Department of Surgery, Tokyo Metropolitan Geriatric Hospital of males and $28.9 \%$ of females developed delirium and abnormal behaviour. Abnormal behaviour of demented patients was not defined as due to delirium or as dementia itself, so it was included in the classification "delirium and abnormal behaviour" becouse of the same aspect in terms of practical nursing care. The following factors were found to be statistically related to the occurrence of postoperative delirum and abnormal behaviour: disability in daily life, dementia, disturbance of hearing. Scores of HDS-R was closely related with the possibility of postoperative delirium and abnormal behaviour.

Key words: Postoperative delirium and abnormal behaviour, QOL, Dementia, HDS-R

(Jpn J Geriat 1994; 31: 633-638.) 